\title{
A NEW FRAMEWORK OF CORPORATE GOVERNANCE FOR WAQF: A PRELIMINARY PROPOSAL
}

\author{
Mohammad Abdullah*
}

\begin{abstract}
The global cumulative waqf assets have been estimated to be worth $\$ 105$ billion. Though, this estimation is not based on exact data, it reflects only a glimpse of what the institution of waqf may entail in the process of and struggle for socio-economic upliftment of the ummah. However, despite possessing the potential of improving society, a substantial proportion of total awqāf is still lying dormant across the world. In modern day economy, waqf has taken a new trajectory, both as a product and as an institution/legal entity, especially in the Islamic finance industry. Consequently, this scenario automatically demands that the institution be fairly regulated and closely monitored. However, not much has been written in the corporate governance area of waqf. This article has three aims: firstly, to briefly examine the salient features of waqf from the perspective of fiqh al-awqāf, secondly, to explore the evolution of the figh al-awqāf in the light of waqf being metamorphosed into a corporation-like entity, and finally, to propose the possibilities of how a corporate governance model can be developed for the institution based on the existing waqf rulings and modern regulatory guidelines.
\end{abstract}

\section{Introduction}

Waqf (plural; awqäf) denotes an Islamic perpetual charitable institution. The practice of waqf has its origin in the Medinan period of prophetic life (622632 A.D). Waqf as an institution evolved in the eighth century A.D, and vastly proliferated in the subsequent centuries (Hennigan, 2004).

The institution of waqf primarily serves two objectives. On the one hand, in spiritual terms, waqf provides a vehicle for perpetual reward for a wäqif (donor), on the other, it confers a myriad of socio-economic benefits on the whole community in general, and on the underprivileged section of the society in particular. As far as the first objective of waqf is concerned i.e. spiritual reward in Hereafter, it is, in fact, immediately achieved once the deed of waqf is formally executed. However, since the second objective of waqf is rooted in the material provisions of benefits to the beneficiaries, it demands for a sustained consistency in the process of waqf management and fairness in the mechanism of revenue/ usufruct distribution. 
From the beneficiaries' perspective, efficient management of a waqf is as critically significant as the endowment itself. In fact, ultimately the beneficiaries receive a portion of what is generated as the revenues of the waqf corpus, and hence they should be, in general, more concerned about its efficient management and fair distributional policies than any other aspect of the institution.

Waqf embodies a typical example of community property in which the interest of the whole community is vested, albeit, in different capacities. Notably, in a waqf khayri (philanthropic waqf) certain purposes, rather than persons, are designated as the main beneficiaries. In comparison, in a waqf ahli (private/family waqf), specifically nominated individuals become beneficiaries (Oberauer, 2013). Thus, it is evident that in a philanthropic waqf, each member of the community is a potential beneficiary, as he/she may possibly qualify for the benefits merely by subscribing to the given purpose or by becoming a part of the purpose for which the waqf has been founded.

In general, compared to philanthropic waqf, a private/family waqf is regarded as restricted in its beneficial character, as it does not include the community as a whole into its domain. However, though in an indirect way, ultimately, a private/family waqf too turns to the community. This notion is best manifested in a scenario where the nominated beneficiaries are no longer existent, and the accruing benefits are diverted to the poor and needy of the community (alMawsū'ah, 2006). With this notion in view, it may be argued that, in one way or another, all awqäf belong to the community and hence, there is a greater need to ensure that the interest of the community (as the stakeholders of waqf) is protected in a consistent manner.

Arguably, unlike the traditional versions of waqf-administrative mechanisms in which, generally, it was appreciated that different awqäf were governed, managed and administrated by individually appointed mutawallis (trustees), the modern trend in waqf industry seeks to appreciate the institutional management of collectively pooled waqf properties (Çizakça, 2011). To this end, there has been a noted shift in both the paradigm of waqf donations and the parameters of their management. Remarkably, due to the marked changes in means, methods, mechanisms and management of modern waqf donations and their administration, the demand to explore the corporate structure of waqf and its governance framework is bound to rise across the board.

Corporate governance, in general, defines the rights, roles and responsibilities of both the principals and agents of a corporation along with determining the underlying "relationships between a company's management, its board, its shareholders and other stakeholders" (OECD, 2004: 11). A good framework of corporate governance helps to improve the overall credibility of a given institution/company and enhances the confidence of its stakeholders. Thus, a 
proper governance framework for a waqf corporation would not only contribute to bring greater accountability and transparency in the operation, but would also play a crucial role in enhancing the long term health of the institution itself (Dusuki et al, 2012).

At this point, it is worth noting that there is a thin line between the early attempts of consolidating different waqf properties into groups and subjecting them under the administration of few state-appointed de facto mutawallis (waqf administrators), and what the recent demands for institutional mutawallis are directed to. In the case of the former, apparently the honesty, transparency and management skills of mutawallis (waqf administrator) and the system were seen with a pinch of scepticism by the community (Kahf, 1999). However, a recent trend shows that these three characteristics, combined with the element of accountability, make the institutional administration of waqf more attractive and trustworthy. With other factors aside, for the modern waqf industry, the credibility of an institutional mutawalli has greater precedence over that of an individual mutawalli. This phenomenon may be best explained by referring to the principal-agency problem, which is inherent in individual mutawalli to a greater extent than in the institutional mutawalli. In fact, in the case of institutional mutawalli, the principal-agency problem is substantially resolved by virtue of it being formally incorporated which makes the corporation subject to both the regulation and monitoring (Hashim, 2013).

Apart from these, the modern concept of 'professionalism' in different sectors has caused a subtle change in the equations of preference for various stakeholders and in this regard, the waqf sector is no exception. Additionally, the phenomenon of globalisation has also been an agent of change in the modern waqf industry. To this end, endowers from a spectrum of geographical locations could easily participate and contribute in the pool of a waqf which is being managed by some international charity organisations overseas (Nadwi and Kroessin, 2013).

In a statistical survey carried out by Ernst \& Young in 2010, the global waqf industry has been estimated to be worth more than $\$ 105$ billion (IFN, 2012). However, the accuracy of this figure is fiercely disputed with the claims that since a larger portion of waqf is managed on individual levels, it is almost impossible to figure out the exact worth of the industry with precision. By comparison, in another informal estimation, the total market value of the industry has been suggested to be worth approximately $\$ 1$ trillion, out of which Malaysia, Saudi Arabia and Egypt are believed to be in possession of $\$ 325.2, \$ 266.6$ and $\$ 82$ billion waqf assets respectively (IFN, 2012).

With these facts and figures in mind, the seriousness of effective waqf management could be hardly over-emphasised. Also, for a consistent and sustainable development of the industry, the mechanism of efficiency, 
accountability, transparency, monitoring and control would have to be installed in the system. To this end, the need for a proper framework of governance for the waqf corporations has assumed an unparalleled level of significance.

\section{Waqf governance: an overview of past and present}

In the jurisprudential discourse of waqf, the deed of Omar ibn al-Khattab (R.A.) occupies cardinal status with reference to permissibility, legality, applicability, practicality and other technicalities of a typical waqf deed (al Asqalani 2001; Ibn al-Qudamah, 1997). In fact, the deed of Omar (R.A.) is deemed as the primary source of waqf jurisprudence by the early jurists of Islamic history. Perhaps that is why in almost all major figh books, the waqf of Omar (R.A.) along with the transcript of his conversation with the Prophet (pbuh) is repeatedly quoted in the chapters discussing waqf-rulings (Kahf, 1999).

Notwithstanding this, in the classical fiqh-literature, most of the waqfgoverning issues have been discussed in an atomistic manner instead of being deliberated with a holistic approach. Possibly, two main reasons may be attributed to this phenomenon. Firstly, the governing structure of waqf continued to evolve until the third century $\mathrm{AH}$ through the application of analogical reasoning by the early jurists (Hennigan, 2004). The mammoth task of deriving waqf related rulings through the application of analogical reasoning was necessitated due to the lack of explicit primary sources which could define and govern each jurisprudential aspect of waqf in a comprehensive manner. The inevitable implication of this scenario manifested itself in the form of repeated discussions among the early jurists on partial and isolated components of the institution, compared to the coverage of an all-inclusive framework of waqf governance in one place (Hennigan, 2004). Secondly, since most of the early examples of waqf were of a separate nature, founded by individuals, managed and administered by the individually nominated mutawallis in accordance to the aspirations of the founder, most $a w q a \bar{f} f$ deeds required a separate form of jurisprudential discussion (Coulson, 2007).

In terms of the governing conditions and regulations of a waqf, the wäqif (endower/donor) enjoys an absolute discretionary power to set up the administrative guidelines, criteria of beneficiaries' selection and principles of its revenue distribution. In this regard, the jurisprudential maxim "shart al-wäqif kal nas al-shäri 'i" (the stipulations of wäqif holds the status of the legislator) constitutes the crux of the related rulings (Zuhayli, 1996: 156). Though the extension of this authority to a wäqif expanded the domain of flexibility to the endower in a micro term, however, it delimited the possibilities of uniformity in the governing structure of waqf on the macro 
level. To this end, a vast array of variations in the stipulations of the early waqf-deeds demanded the classical jurists to exert themselves to examine and discuss the shari' $a h$ validity of individual deeds rather than providing them with enough scope to delve into the possibility of a uniform framework of waqf governance (Hennigan, 2004).

Though the jurisprudence of waqf successfully produced a plausible legal framework of separation between actual and beneficial ownerships of a waqf as early as second century $\mathrm{AH}$, however, it could not overtly declare the institution as a separate legal entity until recently (AAOIFI, 2010; Uthmani, 2008). Perhaps, an early consensus on the legal status of a waqf would have saved much effort of the later jurists expounding upon the question of who, actually, owns the subject matter of a waqf. In addition, perhaps a jurisprudential resolution over the legal status of a waqf would have prepared the canvas for recognition of a waqf-based legal entity in as early as medieval Islamic societies (Kuran, 2003).

This proposition is specifically relevant to the opinion of critics who suggest that if waqf had developed into a corporation-like entity in classical or medieval period, the potential viability, sustainability and durability of the institution would have improved substantially (Kuran, 2003). This is, however, a highly debatable notion, as the historical records reveal that the fate of waqf has not been as much attached to the question of its legal status as has been tied with the political stability or instability of Islamic regimes (Chapra, 2008). Additionally, it has also been argued that it was impossible for the classical or medieval waqf to transform into a corporation-like entity, as the concept of corporation itself evolved as late as the $16^{\text {th }}$ century, and that too in some peculiar circumstances which were completely alien to Islamic territories (Abbasi, 2012, Çizakça, 2012).

The institution of waqf continued expanding its domain until it reached its zenith during the Ottoman period (Çizakça, 2000). In fact, it was during the colonial period that the institution of waqf sustained severe blows which marginally aborted the practice of establishing new awqäf (Kozlowaski, 1985). This phenomenon culminated especially after the Treaty of Paris in 1860 in which the abolition of waqf was among the primary conditions imposed by the British negotiators to advance loans to the Ottoman authority (Çizakça, 2000). However, in the wake of decolonisation in Muslim lands, along with other positive developments, consistent efforts have been poured in by the community to revitalise the functions and operations of this glorious institution both as a concept and as a practice. To this end, though there are a number of identified challenges and obstacles en route, however, mainly three of them could be regarded as central ones. They may be summarised as follows: 
1. Revival of traditional/old waqf properties by resorting to the legal and financial means as per the requirements of specific cases.

2. Re-invigorating the confidence of the community in the practice of waqf.

3. Rescheduling the structures and frameworks of management and governance of the institution in line with the modern needs and requirements of the time.

Importantly, the transitional period between the past and present of waqf has created a vacuum in the administrative and managerial structure of the institution. The pitch, patterns and priorities of traditional waqf management practices do not necessarily comply with the modern trends and dynamics of existing corporate governing frameworks. Whereas, the applied elasticity in tools and methods of making waqf has expanded the domain of waqf to embrace cash, stocks and other mobile and intangible assets as valid subject matters of waqf, the management framework of the practice has yet to be fully transformed into a corporate structure (Mahed, 2009; Mohsin, 2009). Furthermore, alongside other institutional adaptations, the models and paradigm of waqf both as a concept and as a practice need to be more transparent and more pragmatic. Whereas transparency in the governing mechanism is vital to confidence-building, pragmatism would entail wider prospects and greater avenues for applying the need-oriented approaches towards the institution of waqf.

Traditionally, the functions and operation of a typical waqf have been directly or indirectly dictated by the set of conditions stipulated by the wäqif (donor/ endower) himself. Thus most often the classical governing structures of waqf would have been formulated in compliance with the expressly pronounced objectives of wäqifs on individual levels. In this context, the possibility of administrating waqf on individual basis was regarded as a reflection of the great freedom available to the individuals with reference to the properties owned by them. It is suggested that, in this way, the institution was more efficient, effective, productive and relatively more competitive in terms of its functional structure, smooth operation, revenue generation and in the depth and breadth of its outreach to the deserving entities (Kahf, 1999).

The first noted divergence from this method of waqf governance has been traced to the Umayyad period. In the year $736 \mathrm{AD}$, for the first time in Islamic history, an Egyptian Judge, Tawba ibn-Namir introduced the register of waqf in order to bring the institution under the direct regulatory control of the state (Coulson, 2007). Since then, different attempts were made to control the institution either by the state appointed officials directly or, to the least, by ushering in the involvement of regulatory-mechanism indirectly. However in general, waqf continued maintaining its independence from the state, and the institution enjoyed 
the virtual status of the third sector/voluntary sector of economy at large (Kahf, 1999). In fact, the function of medieval waqf essentially set forth the beginning stage for what is now termed as social enterprise (Singer, 2008).

Apparently, the nomination of mutawalli (waqf administrator) in the early Islamic societies was carried out on the basis of either the merit of individual's piety or his nearness to the wäqif. This method of mutawalli selection would have been more productive mainly due to two reasons. Firstly, most of the traditional waqfs were in the form of already revenue-generating immovable properties which would require, in general, an honest administrator to look after the properties rather than requiring individuals of proven managerial expertise and extra administrative skills. In fact, the main criterion for the selection and appointment of a mutawalli was the latter's ability to safeguard the corpus of waqf and to not let it be exposed to the risk of loss or corruption (Kahf, 1999).

Secondly, most often the geographical location of the given properties would have fallen in the locality of the wäqif himself; providing him with enough scope to oversee the management and administration of the same, or in his absence by his heirs. This tradition of mutawalli appointment was followed in the subsequent waqf deeds as a general principle, except in rare cases where no mutawalli was nominated in the deed, and eventually the $q \bar{a} d \bar{l}$ would have had the final discretionary authority to delegate this responsibility to individuals of proven piety (Powers, 1993).

\section{Need and significance of the corporate structure of waqf and its governance}

The jurisprudential framework of waqf is moulded on a distinctive and immaculate design which scarcely has had a parallel, at least in the sphere of charitable institutions. The mark of this distinction is rooted in the intrinsic flexibility and structural elasticity of jurisprudence of waqf and its need-oriented adaptation mechanism. This salient feature of waqf is best embodied through the conferment of a myriad of possibilities to all fundamental characters of the institution. Be it a wäqif (waqf administrator), mawqü bihi (the object of waqf), mawqüf 'alayh (beneficiaries) or mutawalli (trustee/waqf administrator), all is subject to a broad range of possible varieties. The central point of this practical flexibility is characterised by the notion of expanding the domain of social welfare as wide as possible and that too in a perpetual manner (Abu Zuhra, 1972).

Perhaps, in modern times, the nature of dynamism which is inherently embedded in the framework of waqf-management would be under-utilised if a suited structure of corporation is not explored for the management of the existing $a w q \bar{a} f$. In fact, of late, due to renewed calls for revival of awqäf coupled with the 
appeal of active community participation in the institution, it is only natural that the demands for effective waqf management practices intensify. For this purpose, the older versions of charity organisations might have to be properly transformed into corporations as per the specific requirements of the different jurisdictions (Mahed, 2009).

The central theme of the waqf corporations should be characterised in the light of both shari'ah injunctions and the requirements of legal technicalities of the land. In most cases, apparently, there are more affinities between jurisprudence of waqf and the rules pertaining to the charitable entities than the contradictions in them. For instance, in the context of common law, waqf is equated with charitable trust and thus, is commonly perceived to fit in the legal framework of trust (Marwah and Bolz, 2009).

The modern fiqh al-awqäf (jurisprudence of waqf) has recognised waqf as a separate "legal entity or 'theimmah' that may engage in selling, buying, letting and borrowing" (Marwah and Bolz, 2009: 815). This recognition, in fact, has spurred the possibilities of transforming the waqf into the structure of a modern company/corporation. This new development is, seemingly, in congruence to the special nature and peculiar characteristics of waqf in terms of ensuring its longer durability on its own. However, the similarity between the waqf and a modern company does not sustain with reference to the given powers of the shareholders in a company, as they can liquidate it once they have decided to do so (Kahf, 1999). This provision starkly collides with the requirements of a waqf which demands ensuring the perpetuity, irrevocability and inalienability of the institution (Edge, 2008). In this context, either a new framework for the waqfcorporation has to be solicited or a suited amendment would be required in the existing company framework. Under the common law, in fact, the framework of permanent charitable trusts apparently suits best to these peculiarities of waqf. However, the problem with the legal framework of charitable trust as applied under the common law is that it does not deem the waqf ahli (family/private waqf) as 'charitable, and hence curtails the special exemptions and privileges such as waiver of 'rules against perpetuities' from being enjoyed by the family waqf (Stibbard, Russell, and Bromley, 2012). Though, from a purely legal point of view, under the common law a "Charity did not need to be performed through the medium of the trust... and even today it need not be. It could, for example, be carried out through a company" (Matthews, 1996: 1). However, compared to the charitable trust, the provisions of a charitable company do not sit well with the special nature of $w a q f$ so far as the application of cy-pres ${ }^{1}$ doctrines is concerned; which is vital to maintain the perpetuity of waqf. For the purpose of transforming waqf into a corporation structure, the new legal framework introduced by the Charity Commission UK as 'Charitable Incorporated Organisation' (CIO), may 
be adopted. According to the legal provisions "A CIO is a corporate body (like a company) that can own property, employ staff and enter into other contracts in its own name (rather than in the names of the trustees) (Charity Commission, 2012). However, adoption of this structure would entail for the waqf-corporation to comply with its regulatory and governance guidelines which may, occasionally, conflict with some jurisprudential aspects of waqf.

Hence, for the time being, if the existing framework of the corporation is to be sought for waqf management, possibly, its legal loopholes with reference to the special nature of waqf could be compensated only through the introduction of a strong mechanism of governance. To this end, the issue of waqf governance can be treated under the guidance of the traditional fiqh al-awqäf principle which holds that if the wäqif has stipulated that multiple mutawallis would administer the waqf, any reduction in the stipulated number of mutawalli would not be allowed. It is suggested that the rationale of this principle is "that the wäqif did not rely on concentration of full power in a single hand" in the matter of his waqf (al-Mawsū'ah, 2006: 220). Hence, a framework of governance which may resist the concentration of power in a single or few hands can match the peculiar nature of waqf in the modern context. In this regard, for example, the corporate governance guidelines as proposed in the common law propel the scope of 'best practices' in the industry, which ultimately compliments the sharī'ah-oriented recommendations too (Dusuki et al, 2012: 683). In fact, "the sharia and Western governance do have many principles in common such as the aim of ensuring fairness, transparency and accountability" (Foster, 2013:4).

A tailor-made framework of greater transparency, accountability and effective management of a waqf-corporation could be achieved through maintaining a fair compliance with the codes and ethics of the available corporate governance guidelines (FRC, 2012). Additionally, in order to infuse the spirit of shari ${ }^{\prime} a h$ in the structure of the available governance framework, some core principles and specific elements of maquassid al-sharī $a h$ (the higher objectives of sharī'ah) would have to be voluntarily incorporated into the waqf corporations. This may be materialised through embedding the concept of 'adl (justice), sidq (honesty), mașlaha (social welfare), rifq (being considerate to others), amānah (moral integrity), dayānah (self-accountability) and mu'äwanah (mutual cooperation) in the ethical codes of governance. The infusion of these salient features of maqassid in the framework of governance would not only foster an Islamic environment in the work place but would also boost the level of shari'ah-orientation in all stakeholders (Dusuki, 2008).

In the process of formulating a governance framework for the waqfcorporation, infusion of the above-mentioned key maqassid-oriented elements should be emphasised upon from the very beginning. In this process, right from 
the members of the waqf-corporation to other stakeholders, all have to be given fair and proportionate representation in the board of trustees/directors. This mechanism would provide a better canvas of democratic communication and would ultimately enhance the confidence of the community itself in the institution (IFSB, 2006: Principle 1.1). Moreover, perhaps by appointing an additional executive to liaise between different stakeholders and trustees, a plausible pitch for exchange of good ideas and relevant thoughts could be shaped and served across the board.

Though in a limited capacity, the roles and responsibilities of the trustees/ directors coincide with that of a $q \bar{a} d \bar{l}$ in an Islamic polity. These include appointing the management team, fixing the wages, setting up the internal monitoring and regulatory criteria and providing internal supervision and best advice to the management. This analogy between the role of a waqf institution's trustees and $q \bar{a} \underline{d} \bar{l}$ is explicitly evident in cases where the wäqif has neither nominated any mutawalli nor has left a formal deed. In such a scenario, the onus lies upon the qạd $\bar{l}$ to appoint a suitable mutawalli for the property, to fix his/ her wage, to regulate the terms of management and to provide supervision and suitable advice to the mutawalli (al-Mawsū'ah, 2006). From a different angle, in the modern context, the status of trustees/directors is also comparable with the de jure mutawalli himself too. Similar to the mutawalli who owes fiduciary duty to the wäqif and the beneficiaries, directors/trustees too are obliged to fulfil their fiduciary obligations to the shareholders/beneficiaries by the legal provision. In this context, honouring the fiduciary obligation would mean

"...That the fiduciary must act solely in the interest of his principal: the fiduciary must act to secure his principal's best interest, and must not allow his own self-interest, or the interest of others, to govern his behaviour in any way that would conflict with the principal's best interest" (Penner, 2010: 19).

Hence, the nomination/election criteria for the board members/trustees should be mooted with this analogy in view. This analogical comparison should ensure that no trustee is elected on the merit of academic or professional credentials only with the exclusion of his/her shari' $a h$ knowledge and religious orientation or vice versa. Instead, a blend of the two qualifications and relevant experience should be taken into consideration prior to setting forth the stage for their entry in general. Variety in the educational backgrounds of directors is always recommendable (IFSB, 2006: principle 1.1). In fact, a team of trustees composed of experts from different fields of expertise would broaden the horizon of diversity, mutual interaction and coverage of all appropriate dimensions in the decision making process (Hashim, 2013). 
As far as the remuneration of the executive trustees is concerned, it may be fixed in a competitive term. Though, a good number of them would be providing their services on voluntary basis, the provision of good remuneration for others is vital to retain competent and eligible members on the board. Retaining competent board members is crucial in view of the fact that it is they in whose leadership the entire operation is executed (Charity Commission, 2012). Presumably, paying slightly higher remuneration to a competent board for the prudent and smooth functioning of the operation is more justifiable than to cutting the expenses at the cost of exposing the corporation to various risks. In fact, the incompetency of the board may cause reputational risk to the institution (Coyle, 2004).

The criteria of the selection of the management team in general may be formulated on equal terms with other similar corporations with the exception of giving a special preference to those individuals who share the vision and ideals of the waqf institution. Apart from this, the executives and management team should be inducted into the philosophy and ideals of waqf prior to delegating them the practical responsibilities of the operation. If the values, ethos and ideals of the institution are successfully infused in the work environment, this may help the institution to attract and retain an efficient workforce in a much cost-effective manner. By being inspired by the ideals and objectives of the institution, individuals of high moral and ethical orientation may prefer to dedicate their services for the social and humanitarian causes over relatively more lucrative offers. Ideally, the management team should comprise of a separate section of specialists, who know the fiqh al-awqäf inside out along with being well-versed with the legal technicalities of a waqf deed. The team should be competent enough to ably exploit the flexibility of fiqh al-awqäf to mould a specific deed in such a plausible manner which would best suit the objectives of the donor and alongside conform to the legal requirements of the land.

Importantly, the waqf contributions made through cash, stocks, sukuk (Sharī'ah-compliant bonds) and commercial properties would require a special team of experts to manage them prudently. In particular, cash waqf requires the services of a fund manager to invest and manage them in line with the special requirements of fiqh al-awqäf (Mohsin, 2009). For this purpose, on the one hand, shari ${ }^{\top} a h$ filtering criteria of investment must be taken into consideration, and on the other hand, a great degree of caution should be exercised to ensure that the corpus of waqf is not exposed to the risk of loss or diminution. To this end, in line with the needs of different circumstances, the services of a fund manager may also be outsourced, provided the special nature and requirements of cash waqf are communicated to the service provider in advance (Çizakça, 2011). 
In addition, services of volunteers should be availed in different capacities, and the concept and culture of donating time and energy for charitable purposes should be promoted by the corporation. This may lead to cost-effectiveness of the operation and also provide the advantage of garnering a wider support and participation of the community in this process.

Furthermore, involvement of the reputed shari'ah scholars in the whole operation both at the executive and non-executive levels may work to improve the confidence of donors on one hand, and would help prepare a sound environment of internal shari ${ }^{\top} a h$ monitoring and auditing on the other. Remarkably, since the practice of waqf relies on a deep socio-spiritual-orientation of donors, active association of sharī'ah scholars with the corporation at different levels would presumably authenticate the practice from this angle as well. As a result, this may boost the level of spiritual contentment of the donors to a great degree. Thus, perhaps a board comprising of the donors, sharī $a h$ scholars and other elected individuals of appropriate expertise, relevant experience and high qualification may represent the interest of various stakeholders in the best possible manner (IFSB, 2006: principle 1.1). In this process, an appointed executive trustee may be entrusted with the responsibility of liaising among the involved parties, and of communicating their ideas and concerns towards each other in a cogent and convenient manner. This provision may significantly reduce the burden of convening the board meetings every now and then, and would help in maintaining the flow of ideas in a precise and timely manner.

\section{The principal/agent relationship and fiduciary obligation of waqf- corporation: few suggestions}

In the light of the foregoing analysis it may be concluded that by developing waqf into a corporation three vital objectives could be served. Firstly, the independent nature of $w a q f$ is maintained as a separate legal entity. Secondly, the legal requirements of fulfilling the fiduciary duty by the corporation would help reduce the agency problem to a marginal level. And thirdly, the legal provision of installing an appropriate governance mechanism would eliminate any possibility of concentrating the power of property-disposition into a single hand.

At this juncture, it is worth suggesting that in this process the role of the wäqif must not be confined to a passive donor only. As this may eventually result into fostering a less competitive environment in terms of effective management and greater transparency among the waqf corporations. Instead, in a similar situation, the primary focus of the waqf corporations may shift from maintaining good governance and efficiency, to concentration of efforts on media campaigning and advertising to raise funds without being bothered about the high expenses 
involved in the process. This phenomenon becomes more probable if the mechanism of internal control and external monitoring is not scrutinised properly (Iqbal \& Mirakhor, 2007). In fact, lack of competitiveness in waqf management practices is neither good for the long term health of the institution nor appropriate for consolidating the confidence of an existing or potential donor.

It may be suggested that a fairly active and properly informed donor mindset could be the stepping stone in the process of ensuring good governance of a waqf corporation. Ideally, an active donor should scrutinise the credentials of the waqf organisation before deciding to avail its services as of a de facto mutawalli. Arguably, to draw an analogy of the ideal relationship between a potential wäqif (donor) and the institutional mutawalli, the stages of donor's choices and priorities may be divided into three phases. In the first phase, ideally the relationship between the two should be that of a potential investor and stock broker. The philosophy of this relationship necessitates the application of rigorous scrutiny to the authenticity, competitive fee, quality of services and ease of accessibility to the investor.

In the second phase, the credentials of the institutional mutawalli should be evaluated by the donor on the parameters of a good fund manager. In this phase, similar to a fund manager, the institutional mutawalli should be judged in terms of its trustworthiness, quality of stewardship, consistency in performance, competitiveness, relevant experience, managerial skills and discretionary competence. Technically, since both the fund manager and the mutawalli owe fiduciary duties to investors and donors respectively, the yardstick of examining the credentials of the former should be applied to measure the competency of the latter as well.

In the final phase, the donor (wäqif) should presume his position as that of a shareholder in a limited company. At this stage, it is incumbent upon the donors to ensure that along with abiding by the stake-holder theory, the waqf-corporation is equally concerned to safeguard their (the donors') interest too. Though, unlike the for-profit-corporations, in the non-profit or charity institutions, the concept of share-holders does not apply; and the donors are regarded as the members of the organisation (Charity Commission, 2012). However, it may be suggested that with reference to waqf corporations, donors should be recognised as 'virtual ${ }^{2}$ shareholders', and the idea of their 'virtual dividend' should also be postulated. According to this theory, protecting the corpus of waqf perpetually (the 'virtual share' of donor) and striving to magnify its underlying revenues/ benefits (the 'virtual dividends') becomes the primary interest of the wäqif (the 'virtual shareholder'), which must be safeguarded by the corporation.

To illustrate this proposition, it is essential to note that from the shari'ah perspective the promised reward of a waqf in the Hereafter is perpetual only 
because of the perpetual nature of its charitable benefits in this world. The shari'ah premise upon which the concept of the recurring reward of a waqf is based is a prophetic hadith which stated that after the demise of a believer, there are only three possible sources of addition to his/her sum of virtues. Out of these three, sadaqah järiyah (a continuous charity) leads the list (Muslim/1631). Since a waqf is intrinsically perpetual, hence it qualifies the criterion of sadaqah jariyah. Considering this criterion, it is almost obvious that the perpetual nature of a charity is the primary condition for the continuity of the promised reward. And, this is why the majority of scholars did not see an edible or consumable commodity fit to become the subject matter of a waqf, since these would not provide perpetual benefits (Ibn Qudama, 1997).

Based upon the foregoing hypothesis, it is arguable that if a waqf is terminated after a while due to a lack of the wäqif's seriousness or negligence, the underlying benefits would stop recurring, and hence, the provision of his perpetual reward would also be jeopardised. This lack of seriousness on the part of the donor may be reflected in the form of his indifference in selecting a fit and proper institutional mutawalli, for example. Hence, while it is mandatory for the wäqif to rigorously scrutinise the credentials of the mutawalli, the mutawalli too is obliged to ensure the perpetuity of the given corpus. Additionally, building upon the same hypothesis, it may be propounded that though the perpetuity of the donors' reward is almost ensured with the establishment of a waqf deed by the active wäqifs, the amount of the expected reward would vary according to the size and scale of the recurring benefits from the given properties. To further simplify this thesis, for instance, it is worth considering that if a waqf endowed by $\mathrm{X}$ suffices to supply drinkable water to one hundred people; the expected reward for $\mathrm{X}$ would be greater than the expected reward of $\mathrm{Y}$, whose waqf, with other variables being constant, suffices only for fifty people. Thus, it is arguable that the expected amount of reward for a waqf depends on the size and scale of its underlying benefits. To this end, though in an indirect way, the shari' $a h$ validity of this proposition may be sought by citing the prophetic hadith which holds that "Whosoever takes an initiative towards a virtuous deed would receive the reward for his initiative and also for the actions of all those who follow him in this" (Muslim/1017). The point of reference in this tradition lies in the second part of the hadith, which implies that each time the number of the followers grows, the amount of reward for the initiator also increases. Hence, the sum total of initiators' promised reward depends here on the total number of his followers. Similarly, in a waqf, the sum total of the donor's reward would depend upon the total amount of benefits accrued to the beneficiaries. Interestingly, the context of the above mentioned hadith reveals that this statement of the Prophet (pbuh) is linked with his exhortation to the practice of charity (Muslim/1017). With this 
proposition in mind, it may be argued that with reference to waqf, the size of the virtual dividend of a donor could be improved through managing his/her waqf efficiently so that its yields may grow and the incurring benefits may reach to a greater number of beneficiaries.

In a nutshell, the interest of a donor could be best served only if the related waqf corporation is sincerely committed to ensure the continuity of his waqf along with striving to improve his virtual dividend through an efficient management of the given corpus. In this regard, it may be suggested that the nature of the fiduciary duty owed by the waqf-corporation to its donors would be synonymous to the one owed by a for-profit company to its shareholders or by a mudārib (entrepreneur) to the rab al-māl (capital provider) (IFSB, 2006: principle 2.1). Therefore, along with other stake-holders, ensuring the protection of donors' interest too would constitute the primary responsibility of the institution. Perhaps, the application of these three criteria of a donor's choice in terms of selecting a waqf-corporation to rely upon may spur a greater sense of competitiveness and transparency among the waqf corporations, which in turn would strengthen the structure of good governance in the industry.

\section{Conclusion}

Historically, waqf has represented the philanthropic sector of Islamic economy. For a long period of its history, most of the awqäf had been composed of real estates which were managed by individually appointed mutawallis and governed by the sets of stipulations articulated by the wäqifs. Compared to this traditional mechanism, in the modern day waqf practices both the means of waqf donations and methods of their management have witnessed a noted change of trajectory. While most of the new awq $\bar{a} f$ are made in the form of cash or intangible assetclasses such as stocks and sukuk, the responsibility of their management, in general, is being borne by the institutional mutawallis .

To this end, there has arisen a greater need for pragmatism of approach towards waqf management practices on the corporate level. Arguably, in the process of moulding an effective corporate governance framework for waqf as per the modern requirements, stipulating an absolute compliance with the classical waqfrulings may confine the scope of dynamism in the institution. Also, perhaps, in the formulation of a good governance mechanism, the role of an active donor would be critically vital.

Additionally, it seems appropriate to suggest some fundamental changes and adaptations in the classical waqf governance model in line with the need of the time. Also, arguably, for different jurisdictions some tailor-made new paradigms of waqf governance models should be solicited, which may potentially help in 
resolving the exclusive problematic spheres and challenging arenas of their own specific locations.

Finally, as proposed in this paper, the concepts of virtual shareholder (for the wäqif), virtual share (for the waqf) and virtual dividend (return on waqf) should be recognised. This, in turn, would help to create a competitive environment amongst the institutional mutawallis and promote greater transparency in waqf management practices.

\section{Notes}

* Mohammad Abdullah is a PhD researcher (sponsored by IDB) at the Markfield Institute of Higher Education; Leicestershire, UK. He holds Master degree in Islamic Banking and Finance, and a Bachelor degree in Sharí'ah studies. Abdullah serves as secretary Sharī'ah board for IFAAS (Caribbean) and is also associated with Islamic Relief, U.K. as a PG research fellow. He may be contacted at abdullahfaizi99@hotmail.co.uk. The author is indebted to Shaikh Faizal Manjoo for his consistent guidance throughout the preparation of this paper. Also, the author is thankful to Professor Humayon Dar and Professor Toseef Azid for their continuous support. Finally, the author would like to thank his colleague Ms. Sameen Zafar for her invaluable suggestions.

1. The doctrine of cy-pres holds that if the explicit purpose/object of a charitable trust fails/terminates, the fund must be steered to some other purposes which are similar to the original one. This doctrine is analogous to the fiqh al-awqäf ruling which states that if the nominated purpose/beneficiaries of a waqf cease to exist, the benefits would be diverted to the other closest purpose (Gardner, 2003).

2. The term 'virtual' here denotes the assumed characters in waqf corporations which are comparable with the actual characters of shareholders/shares/dividends etc. in a for-profit company.

\section{References}

AAOFII, (2010) Shariah Standards for Islamic Financial Institutions, Accounting and Auditing Organisation for Islamic Financial Institutions, Manama, Bahrain, SS no. $33,3 / 4 / 2$.

Abbasi, Z. (2012) God's Law v. Corporation: A Critique of Islamic Law Matters Thesis, Legal Paper Series 5/June 2012: University of Oxford.

Abu Zuhrah, M. (1972) Muhaḍharāt fil waqf, Cairo: Darul Fikr al-Arabi.

Al Asqalani, I. H. (2001) Fath al-Barī Sharah sahịh al-Bukharī, Maktaba Misr, Cairo, vol. 5 pp. 541-71.

Chapra, M. U. (2008) Muslim Civilization: The Causes of Decline and the Need for Reform, the Islamic Foundation, Leicestershire, UK.

Charity Commission (2012) Constitution of a Charitable Incorporated Organisation, available at: http://www.charitycommission.gov.uk/media/94463/ associationmodelconstitution_lowink.pdf, [Accessed on $27^{\text {th }}$ Jan, 2014]. 
Charity Commission (2012) Trustee Expenses and Payments (C11), available at: https://www.charitycommission.gov.uk/publications/cc11.aspx, [Accessed on $28^{\text {th }}$ Jan, 2014].

Çizakça, M. (2012) Why West Asia Declined, available at: http://mpra.ub.unimuenchen.de/41877/, [Accessed on 17 $7^{\text {th }}$ Jan, 2014].

Çizakça, M. (2011) Islamic Capitalism and Finance: Origins, Evolution and the Future: Origins, Evolution and the Future, Gloucestershire: Edward Elgar Publishing Ltd.

Çizakça, M. (2000) A History of Philanthropic Foundations: The Islamic World from the Seventh Century to the Present, Istanbul: Bogazici University Press.

Coulson, N. J. (2007) A History of Islamic Law, Edinburgh: Edinburgh University Press, pp. 32-33.

Coyle, B (2004) Risk Awareness and Corporate Governance, $2^{\text {nd }}$ Edition, UK: Institute of Financial Services.

Dusuki, W.A. et al (2012) Islamic Financial System: Principles \& Operations, Kuala Lumpur: International Shariah Research Academy for Islamic Finance.

Dusuki, W.A. (2008) Islamic Finance: An Old Skeleton in a Modern Dress, Kuala Lumpur: International Shariah Research Academy for Islamic Finance.

Edge, I. (2008) Methods of Avoidance of the Fixed Heirship Rules in Islamic Law: The Islamic Trust, in Trusts \& Trustees, Vol.14, No. 7, pp. 457-465.

Financial Reporting Council, (2012) UK Corporate Governance Code, available at: $\quad$ http://www.frc.org.uk/Our-Work/Publications/Corporate-Governance/UKCorporate-Governance-Code-September-2012.aspx, [Accessed on 21 ${ }^{\text {st }}$ Jan, 2014].

Foster, H. N. (2013) Making People Behave Properly in Islamic Finance: Some General Thoughts, SOAS Law of Islamic Finance Working Papers Series, London: University of London.

Gardner, S. (2003) An Introduction to the Law of Trusts, Oxford: Oxford University Press, $2^{\text {nd }}$ edition.

Hashim, T.S. (2013) Issues on Corporate Waqf, available at: https://www.academia. edu/1830406/120401_Issues_on_Corporate_Waqf, [Accessed on 13 ${ }^{\text {th }}$ Jan, 2014].

Hennigan, P.G. (2004) The Birth of a Legal Institution: The Formation of the Waqf in Third Centuary A.H Hanafi Legal Discourse, Leiden: Brill.

Hodgson, G. S. (1974) The Venture of Islam, 3 vols. Chicago: University Press of Shicago, vol. 2, pp. 124.

Ibn al-Qudamah, M. A. (1997) al-Mughnnī, Dar Ālam al-Kutub, Riyadh: KSA, vol. 8 pp. 231-32.

IFSB (Islamic Financial Services Board) (2006) Guiding Principles on Corporate Governance, available at: http://www.ifsb.org/standard/ifsb3.pdf, [Accessed on $25^{\text {th }}$ Jan, 2014].

Iqbal, Z. \& Mirakhor, A. (2007) An Introduction to Islamic Finance Theory and Practice, Singapore: John Wiley \& Sons (Asia), pp. 227-250.

Islamic Finance News (2012) The Waqf Industry: The Sleeping Giant of Islamic 
Finance, September 2012, vol. 9, issue no. 39.

Kahf, M. (1999) Towards the Revival of Awqäf: A Few Fiqhi Issues to Reconsider, Paper Presented at the Harvard Forum on Islamic Finance and Economics, USA: Harvard university. Available at: http://monzer.kahf.com/papers.html, [Accessed on $20^{\text {th }}$ December 2012].

Kozlowski, C.G (1985) Muslim Endowments and Society in British India, Cambridge: Cambridge University Press.

Kuran, T. (2003) The Provision of Public Goods under Islamic Law: Origins, Impact and Limitations of the Waqf System, Law and Society Review, 35,4.

Mahed, G. (2009) The Corporate Governance of an Organisation Managing Islamic Charitable Endowments (waqf), Corporate Governance in Africa Case Study Series: No 2, available at: http://beautyofwaqf.files.wordpress.com/2011/12/mahed-gaathier. pdf, [Accessed on $27^{\text {th }}$ Jan, 2014].

Marwah, H. and Bolz, K. A. (2009) Waqfs and Trust: a comparative study, in Trusts \& Trustees, vol. 15, No.10, pp 811-816.

Matthews, P. (1996) The New Trust: Obligations without Rights?' in Oakley, AJ (ed) Trend in Contemporary Trust Law, Oxford; Oxford University Press.

al-Mawsū'ah al-Fiqhiyah (2006) Waqf, Kuwait: Wazāratul awqāf wal shu'ûn al Islami, vol. 44, pp. 107-116.

Mohsin, A. Moghda (2009) Cash Waqf: A New Financial Product, Malaysia, Prentice Hall.

Muslim, al-Sahịḥ̣ (1999) “Kitāb al-wasiyah”, in Salih, A. (Ed.), Mawsū'ah al-Hadìth al-Sharif, Darussalam, Riyadh: KSA, Hadith No. 1631.

Muslim, al-Saḥị̣ (1999) “Kitāb al-'Ilm”, in Salih, A. (Ed.), Mawsū'ah al-Hadìth alSharif, Darussalam, Riyadh: KSA, Hadith No. 1017.

Nadwi, M.A. and Kroessin, M (2013) Cash Waqf: Exploring concepts, jurisprudential boundaries and applicability to contemporary Islamic microfinance, Islamic Relief Worldwide, Working Paper Series No. 2013-0x: Birmingham, UK.

Oberauer, N. (2013), Early Doctrines on Waqf Revisited: The Evolution of Islamic Endowment Law in the $2^{\text {nd }}$ Century AH, Islamic Law and Society, No. 20, pp. 1-47.

OECD (Organisation for Economic Co-operation and Development) (2004) Principles of Corporate Governance, France: OECD Publications.

Penner, J.E. (2010) The Law of Trusts, $7^{\text {th }}$ edition, Oxford: Oxford University Press.

Powers, S.D. (1993) The Maliki Family Endowment: Legal Norms And Social Practices, International Journal Of Middle Eastern Studies, 25, pp. 379-407.

Singer, A. (2008) Charity in Islamic Societies, Cambridge: Cambridge University Press.

Stibbard, P. Russell, Q. D. and Bromley, B. (2012) Understanding the waqf in the world of trust, in Trust and Trustee, vol. 18, No. 8. pp. 785-810.

Usmani, M. T. (2008), an Introduction to Islamic Finance, Maktaba Ma'āriful Quran, Karachi, Pakistan, pp. 221-232.

Zuhayli, W. (1996) Al Wașiyah wal waqf fil fiqh al-Islämi, Damascus: Darul Fikr. 